\title{
8.2 Moral and ethical imperatives of family education of ukrainians in the works of ukrainian writers of the late XIX - early XX century
}

Проблема родинного виховання $є$ надзвичайно актуальною для українського суспільства загалом та окремої людини зокрема, адже саме сім'я сприяє первинному пізнанню і засвоєнню норм моралі та етики, формуванню характеру, розвитку волі та почуттів. Сформовані в родині морально-етичні імперативи визначають поведінку молодої людини, рівень їі духовної культури, впливають на процес їі професійного самовизначення та самореалізації.

Сучасна криза соціально-політичної i економічної сфер в Україні призводить до відчуження молодих людей від споконвічних морально-етичних норм i вимог, підштовхує їх до здійснення неправильних кроків на шляху самореалізації.

Морально-етичні імперативи українського родинного виховання складалися упродовж тривалого історичного періоду й знаходяться в центрі уваги педагогів, психологів, культурологів, українознавців, філософів, батьків і вчителів. Проблеми здійснення морально-духовного розвитку дитини в сім'“ грунтовно розкриває Г. Авдіянц [553], роблячи невтішний висновок про те, що сучасний стан суспільства провокує кризу в родині, веде до нівелювання i. найважливішої виховної функції. Сучасні негативні тенденції в українському суспільстві не сприяють моральному становленню та духовному розвитку молодого покоління, що зрештою приводить до проявів морально-етичної незрілості у дорослому житті, а також до наростання соціальної нестабільності, політичної дезорієнтації, деморалізації значної частини суспільства.

Наше дослідження є вкрай необхідним ще й тому, що деякі сучасні наукові розвідки доводять певну втрату сім'єю своїх одвічних традиційних позицій. Автори цих публікацій переконані, що безшлюбність і бездітність, які згідно 3 українською традицією вважалися трагедією людини, насправді належать до переваг, тому що самотній людині легше виживати у технізованому й урбанізованому суспільстві. Цінність індивідуальності стає вищою, ніж цінність 
співтовариства. Якщо сім’я в історичному аспекті традиційно була гарантією соціальної безпеки, то сьогодні з'являються інші інституції, які у цій царині можуть їі замінити (страхові компанії, фонди, товариства тощо). Відповідно до цього у суспільстві все частіше лунають заклики до свободи від сімейних уз, пропагуються безшлюбність і бездітність, пропонуються альтернативи традиційній сім’ї тощо. Зрозуміло, що такі заклики не можуть позитивно впливати на процес збереження й утвердження традиційних родинних імперативів, зокрема морально-етичних.

Важливе місце у висвітленні структури, складу, функцій та способу утворення українських сімей кінця XIX - початку XX століття займають праці таких етнографів та істориків, як: Л. Артюх, М. Грушевського, В. Горленка, Ю. Гошко, П. Єфименка, О. Кравець, В. Наулка, В. Охрімовича, А. Пономарьова, Р. Чмелика та ін. Дослідниками окреслені характерні риси сімейного побуту українців; визначені особливості та специфічні риси різних типів сімей; здійснений аналіз функцій української сім’і та ії структури; простежена еволюція української сім'ї та вплив на неї соціально-економічних, політичних, національних і релігійних чинників.

Активно працювали над вивченням інституту сім’ї, дали конкретні настанови щодо врахування у процесі родинно-сімейного виховання кращих морально-етичних цінностей українські педагоги i психологи, зокрема: Т. Алєксєєнко, М. Боришевський, А. Вихрущ, О. Вишневський, О. Докуніна, К. Журба, Г. Кришталь, В. Мілясва, Т. Пантюк, Т. Руденко, М. Савчин, Н. Скотна, М. Стельмахович, І. Сіданіч, О. Сухомлинська, М. Чепіль та ін.. Велике значення інституту дитинства в традиційній культурі українців, у моральному розвитку дитини в селянській сім'ї досліджували М. Дерлиця, Н. Заглада, Д. Лепкий, Марко Грушевський та ін. Науковці доводять, що основу морально-етичного виховання дітей у родині становили загальнолюдські імперативи та християнські цінності. 
Насамперед з'ясуємо сутність понять «імперативи», «цінності», розкриємо зміст морально-етичного виховання й виокремимо головні морально-етичні імперативи родинного виховання.

За словником української мови [2, т.4], імператив - це беззастережна, категорична вимога; веління, наказ; за словником іншомовних слів [555], імперати́в (від лат. imperativus - владний) - веління, настійна вимога; категоричний імператив - в ідеалістичній етиці німецького філософа I. Канта безумовне моральне веління, яке нібито притаманне розуму, $\epsilon$ вічним i незмінним і покладене в основу моралі, імператив (в філософії) - безумовне моральне веління; категоричний імператив Канта - загальний усеохоплюючий моральний закон, внутрішньо притаманний кожній людині [556].За I. Кантом, існує єдиний фундаментальний моральний принцип: чинити так, аби завжди розглядати інших людей як цілі, а не як засоби. Цей принцип є імперативом (командою), і він є категоричним (застосовується без винятків, у всіх випадках, місцях і обставинах). Він $є$ класичним прикладом етичних теорій, систем моралі, що зосереджуються радше на істинному характері поведінки (і намірах особи), аніж на наслідках цих дій.

Філософську теорію моралі та їі цінностей значно збагатили зарубіжні та вітчизняні філософи. І. Кант першим звернувся до поняття цінностей, розрізнюючи сферу природного буття, підпорядкованого необхідності, й царині моральності; стверджував, що у сфері моралі і релігії зосереджуються кінцеві цілі життя. Подальшого розвитку концепція цінностей набула у вченнях неокантіанців. За теорією В. Віндельбанда, найвищими людськими цінностями $€$ істина, благо, краса і святість. Він наголошує, що цінність - це не реальність, це ідеал, носієм якої виступає наша свідомість [557, с.316].

Мораль і етику, загальнолюдські цінності у рамках християнського світогляду розглядали такі філософи, як Е. Берк, Тейяр де Шарден, М. Шелер. Е. Берк відстоював традиційні цінності добра, шляхетності, справедливості та правди [557, с.53].На думку Тейяра де Шардена, еволюцію людини визначає не лише технічний і науковий прогрес, а й значно більше - прогрес духовний [557, 
с.53]. М. Шелер вважав, що цінності можна осягнути тільки через переживання. До актів переживання цінностей він відносить співчуття, любов, ненависть. Бог для нього - це вища цінність, а любов до Бога - вища форма любові. На його думку, людині слід розвивати в собі духовне начало з тим, щоб досягнути царства вічних цінностей [558, с.23].На переконання вченого, високоморальною $\epsilon$ та людина, котра розуміє важливість християнських цінностей у своєму житті. Він розрізняв чотири групи цінностей: гедоністичні, вітальні, духовні (естетичні, етичні, епістемологічні) та релігійні, осягнення яких відбувається не раціональним шляхом, а на підставі інтуїції [557, с.53].

Сутність понять «цінності», «моральні цінності» розтлумачено у педагогічній, психологічній та філософській літературі. За словами Л. Чупрія, цінності - це ідеї, норми, процеси, відносини матеріального й духовного порядку, які мають об’ єктивну позитивну значимість і здатні задовольнити певні потреби людей. Він вважає, що воістину мудрою є та людина, яка, пройшовши великий життєвий шлях, побудувала цілісну картину світу, в основі якої лежить глибинне розуміння сутності явищ та процесів світу, що витікає із системи високих морально-етичних цінностей [558, с.23-24].

В. Шапар зазначає, що кожній людині властива індивідуальна, специфічна ієрархія особистісних цінностей, яка служить сполучною ланкою між духовною культурою суспільства і духовним світом особистості, між буттям спільним та індивідуальним [557, с.707]. Такої ж думки дотримувався В. Лісовий: цінності відіграють провідну роль в об’єднанні індивідів для спільних, колективних дій; є важливими у забезпеченні основи для єднання людей у нації, цивілізації чи навіть людства [557, с.707].

Отже, цінності виступають регулятором вчинків людини у їі діяльності, в основі яких лежить моральна значущість, i суттєво впливають на суспільне життя.

Виховний ідеал в українській сім’ї формувався протягом усієї історії українського народу. Цей ідеал викристалізувався у формі ставлення в народі до сім’ї і праці, особливостях засвоєння, збереження й розвитку духовної культури, 
вияву громадянських почуттів, дотримання обов'язку, захисту прав і свобод українського народу. Безперечно, досягнення цього ідеалу на практиці залежало від багатьох чинників - державного устрою, світогляду як окремого індивіда, так і суспільства в цілому, моралі та релігії, рівня розвитку культури, національних властивостей тощо.

В сучасних умовах на виховний ідеал має орієнтуватися державна політика, сім’я, освітні заклади, суспільство. Виховний ідеал української нації знаходить своє відображення не тільки в традиціях і звичаях народу, фольклорі, художній літературі, а й у національних освітніх та виховних системах. У виховному ідеалі таїться дух нації. Адже нація зберігається там, де іiі дух, традиції, інтереси визнаються пріоритетними, і захищається всіма засобами, аж до крайніх. Підтвердженням цьому є приклади усієї світової історії.

Виховний ідеал в української родині творився віками і за традицією сьогодні має переходити від старших поколінь до молодших, що його доповнять i вдосконалять. Він знаходиться в одному ряду 3 досягненнями інших цивілізованих народів. Це підтверджує спільність розвитку української сім’ї, иї педагогіки і загальноєвропейського процесу. Адже здобутки одного народу на великому європейському просторі швидко ставали надбанням інших народів. Свідченням цього є те, що педагогічні системи Я. Коменського, Ж. Руссо, Й. Песталоцці, К. Ушинського, А. Макаренка, В. Сухомлинського впевнено знаходили своїх прихильників і послідовників серед усіх народів Європи.

Зрозуміло, що значні зміни в житті українського народу на початку XX ст. призвели до змін у системі виховних орієнтацій, моральних i духовних цінностей. Ці зміни супроводжувалися боротьбою різних педагогічних теорій i позначені багатьма втратами кращих якостей української родини та викривленнями менталітету українця. Отож сьогодні у нашому поступу вперед важко переоцінити значення народних традицій. Відмова від них означала б відмову від своєї національності. Завдяки народній культурі, традиціям зберігається і розвивається культура й освіта сучасних поколінь, національна мова, без якої неможливе існування й самої нації, зберігаються звичаї, здобутки 
мистецької творчості, формується світогляд, народні ідеали, - все те, що творить обличчя народу, вирізняє його з-поміж інших. Виховний ідеал людини - це те найкраще, що створив український народ силою свого творчого генія, у ході віковічної боротьби за своє існування, економічний, культурний і духовний розвиток. Г. Ващенко виділив такі основи виховного ідеалу: національні фізичні і психічні особливості народу; усвідомлення народом свого призначення; християнство і загальноєвропейська культура; висока мораль, чистота і світлість душі; вище, божественне, одухотворене начало; служіння Україні, своєму краю як сенс життя людини; національна свідомість, почуття єдності 3 усією українською спільнотою; патріотична, здорова, національна гордість, національна гідність, любов до інших народів [559].

Виховний ідеал українця за Г. Ващенком складають християнські доброчинності, він має такий узагальнений вигляд: віра, надія, любов, правдивість, твердість у своїй вірі; уміння долати сумніви, зовнішні спокуси; християнський оптимізм, бадьорість; уміння зносити невдачі, нещастя, страждання; душевний спокій і радість; уважне ставлення до інших; піклування про ближніх, розуміння своїх хиб та провин, уміння їх виправляти; уміння боротися зі злом, шанувати батька i матір, не бути рабом своїх тілесних пристрастей, багатства i суєтної слави, бути лагідним i доброзичливим, стримуватися від заздрощів, гордощів і честолюбства, бути чесним і правдивим, не красти і не вбивати, співчувати ближнім, допомагати хворим, убогим, ув’язненим; прощати образи, не мститися, боротися зі злом, особливо, якщо воно поширюється в суспільстві [559]. Виховання в традиції християнської моралі це система формування духовності, де мають бути віра, знання, містичний досвід, моральний кодекс. Воно орієнтує на виховання ідеалу благочестивої людини, яка чітко виконує всі встановлені Богом заповіді і правила в поєднанні 3 духовною піднесеністю й постійним чеканням, готовністю постати перед божественним Суддею. Педагогічний ідеал - духовний розвиток людини, дитини, розкриття в неї містичного досвіду. Він постає як позасоціальний i позачасовий, всезагальний i звертається до соціуму тоді, коли потрібно 
продемонструвати негативні складові внутрішнього світу людини (пороки, недоліки, гріхи), за допомогою яких відбувається рух до ідеалу й ідеального. У християнській моралі більше, ніж у будь-якій іншій теорії, моральність, чесноти пов'язані з текстами, з розповіданням історій особливих, повчально-священних, імперативних [560, с.111-112]. Виходячи із вищеописаних концептуальних положень i наших узагальнень, робимо висновок про необхідність культивування в українській родині таких морально-етичних імперативів, як:

• вияву любові та поваги до своїх батьків, готовності їм допомагати;

• шанування культу предків, який становить основу народних традицій i звичаїв;

- сформованості національної свідомості і самосвідомості, любові до рідної землі і народу;

- розуміння і відчуття духовної єдності поколінь, ролі жінки-матері / чоловіка-батька в ії забезпеченні;

- сформованості високої мовної культури, усвідомлення мови як енергетичної субстанції;

• шанобливого ставлення до історії, культури, звичаїв, традицій свого народу й народів світу;

• усвідомлення власної національної гідності, честі, внутрішньої свободи;

- високої духовної культури особистості, сформованого світогляду, розуміння законів розвитку природи, суспільства;

- дотримання принципів народної і вселюдської моралі: правдивості, справедливості, доброти, працелюбності, гуманного ставлення до людини i довкілля;

- негативного ставлення до проявів безвідповідальності в праці і безгосподарності, утриманства і лінощів, крадіжок суспільної і приватної власності та варварського ставлення до природних багатств;

- високої художньо-естетичної освіченості і вихованості особистості; негативного ставлення до потворного, вміння відрізняти красиве від потворного в мистецтві, побуті, поведінці, зовнішньому вигляді; 
- екологічної культури особистості, гармонії ії відносин із природою; відчуття відповідальності за природу як національну і вселюдську цінність;

- спроможності розвивати пізнавальну активність і культуру розумової праці;

• уміння міжособистісного спілкування, культури спілкування, гуманізму, колективізму, товариськості, доброзичливості, взаємопідтримки, чесності, організованості і дисциплінованості, чемності й порядності.

Відтак родинне виховання є могутнім джерелом формування світогляду, національного духу, світовідчуття і світорозуміння, високої моральності, трудової підготовки, громадянського змужніння, глибоких людських почуттів, любові до матері і батька, бабусі і дідуся, роду і народу, пошани до рідної мови, історії, культури. Найголовнішими морально-етичними рисами українця $\epsilon$ лагідність, щирість, доброта, доброзичливість, гостинність, працьовитість, а ще прагнення до свободи, правди та захисту свого роду і Батьківщини.

Специфіка формування уявлень про засади національного родинного виховання в українському літературному просторі багато в чому завдячує ситуації модерного націєтворення, що позначилася на соціальних і культурних процесах Європи XIX століття. Конечну мету цієї місії української інтелігенції врешті артикулював Іван Франко, як потребу «витворити з величезної етнічної спільноти українського народу українську націю, суспільний культурний організм, здатний до самостійного культурного і політичного життя, відпорний на асиміляційну роботу інших націй, відки б вона не йшла, та притім податний на присвоювання собі в найширшій мірі і в найшвидшім темпі загальнолюдських культурних здобутків, без яких сьогодні жодна нація і жодна хоч і як сильна держава не може остоятися...» [561, с.71]

Для українців цей процес ускладнювався ситуацією занепаду давніх національних громадянських інституцій на користь загальноімперським та неможливістю їх відродження в умовах постійних утисків з боку метрополії. С. Скельчик, аналізуючи прикметні риси патріотично орієнтованого «українофільства», зауважує, що неможливість легальної політичної і навіть 
культурної роботи на ниві національній привела до того, що «...простір національних і опозиційних жестів обмежувався власним домом патріота чи патріотки, його чи їі одягом, стравами, напоями, зачісками, вусами й аркушем паперу, на якому можна було написати оповідання з народного життя і потім прочитати його в колі найближчих друзів або надрукувати під псевдонімом в Австро-Угорщині» [562, с.20]. Ці реалії змушували українську освічену спільноту зосередити свої зусилля на етнографічних та фольклорних студіях, питаннях просвіти, а також процесі, названому Еріком Гобсбаумом [563] «винайденням традиції», який включав у себе ритуалізацію окремих аспектів народного побуту та історичного минулого.

Слід зауважити, що на початку XIX століття становище української літератури переважно визначалося тією обставиною, що іiі творцями виступали українські за походженням дрібні провінційні дворяни, священники, урядовці, про яких М. Зеров зауважив, що «вся ця дрібна провінційна публіка живе переважно духовою справою російської журнальної лектури <..>, але не задовольняється нею цілком і для повного вдоволення естетичного переходить на «неочищенный слог», народну говірку, таку природну й мальовничу і під iii пером. Анекдот 3 народного життя, п’єса 3 сільського побуту, романс українською мовою складений, ефектна приказка, історичний спогад становлять живу естетичну потребу цієї громади, один 3 аксесуарів іiі побуту, оздобу коротких провінціальних сезонів, що припадають на ярмаркові тижні та на час дворянських виборів, розвагу хутірських з’їздів, храмових та іменинних свят» [564, с.101]. Однак таке судження, яке було висловлене більш ніж через століття і явно спрямоване на розв'язання проблем модерного часу має досить дражливі моменти. Звісно, період розвитку української літератури, який М. Петров у своїх досить спірних 3 погляду сьогодення «Нарисах історії української літератури XIX століття» називає «українським псевдокласицизмом», позначений домінуванням в ній «низьких» жанрів, досить нечисленних текстів комедійного характеру, вершинним досягненням серед яких стає «Енеїда» Івана Котляревського. Попри наявність у ній яскравих елементів українського 
побутописання, інтерес до принципів народної родинної моралі у ній відсутній. Український антураж стає засобом бурлеску, саме через неприпустимість для освічених любителів «неочищенного слога», можливості розкриття i обговорення ним проблем моралі. Звідси неоднозначність сприйняття «Енеїди» українськими національними і культурними діячами XIX століття.

Натомість сентименталізм 3 його посиленою увагою до простої людини сприяв ширшому залученню морально-етичної проблематики в український літературний простір. Чи не найвиразніше в цьому контексті виділяються імперативи родинних взаємин батьків і дітей в сентиментальних повістях та оповіданнях Григорія Квітки-Основ'яненка. Артикульовані письменником моральні імперативи визначили цілий ряд літературних канонів, які залишалися абсолютними i непорушними в читацькому середовищі патріотично налаштованого українства. Звісно, насамперед започаткований «Марусею» канон найяскравіше виявляється в образі головної героїні твору. Він надзвичайно збалансований: зовнішня краса стає виявом глибинної внутрішньої гармонії $\mathrm{i}$ цілісності духовного світу героїні. Опис зовнішності Марусі залишається орієнтиром для творення портретних дівочих образів українськими письменниками не лише в класичній літературі, але й в текстах, позначених стилістикою соцреалізму, наприклад, коли мова йде про героїнь романів Михайла Стельмаха: Олени («Правда і кривда»), Оксани, Мирослави («Чотири броди»), Ярини («Дума про тебе»). Водночас, зовсім не випадково його домінування намагається зруйнувати у своєму першому оповіданні «Сила i краса» Володимир Винниченко. Зовнішність його героїні Мотрі виписана як повна антитеза Марусі: «То була краса, що викохується тільки на Україні, але не така, як малюють деякі 3 наших письменників. Не було в неї ні «губок, як пуп’янок, червоних, як добре намисто», ні «підборіддя, як горішок», ні «щок, як повна рожа», і сама вона не «вилискувалась, як маківка на городі». Чорна, без лиску, товста коса; невисокий, трохи випуклий лоб; ніс тонкий, рівний, $з$ живими ніздрями; свіжі, наче дитячі губи, що якось мило загинались на кінцях; легка смага на матових, наче мармурових щоках і великі, надзвичайно великі, 3 
довгими віями, темно-сірі очі, з яких, здавалось, дивлячись, наче лилося якесь тихе, м’яке, ласкаве світло, - то була й уся краса сієї дівчини» [565, с.23]. Це не просто іронія супроти старої традиції, але й бунт В. Винниченка загалом супроти ідеалізації народного характеру в народовському каноні. На цих обставинах більш детально ми вже зупинялися, аналізуючи спроби подолання рустикального дискурсу Володимиром Винниченком [566]. Ще далі у формуванні образу «анти-Марусі» письменник рухається в драмі «Молода кров», в якій пародіюються шаблони старої української мелодрами. Традиційна романтична трагедійність образу зведеної паничем дівчини-покритки замінюється іронічним змалюванням наївності інтелігенції, котра сама виробила на основі романтичної традиції сюжет про ідеальну душу богоданого народу. Героїня п’єси сільська покритка Ївга власне виступає антиподом вже закоріненого в літературну традиції типажу жертви панських забаганок. Швидше вона $є$ втіленням тверезого селянського глузду і практицизму, уміння вдало маніпулювати Антосем, за допомогою педалювання стереотипів, в полоні яких він знаходиться.

Поряд 3 акцентуванням уваги на дівочих чеснотах Марусі, КвіткаОснов'яненко створює яскраву картину родинних стосунків, в основу яких покладено турботу іï членів про рідних, панування батьківського авторитету i поваги з боку молоді до старших, особливо до батька, як головного транслятора i охоронця родинної моралі. Батько Марусі Наум Дрот, заможний український господар, шанована громадою людина, - незаперечний авторитет і охоронець звичаю. Кожен його крок є виявом далекоглядності століттями випробуваних приписів патріархальної моралі. Коли він відмовляється піти назустріч щирим почуттям молодих закоханих і віддати заміж Марусю за Василя, це не трактується автором як батьківське самодурство чи користолюбство. Натомість мова йде про усвідомлення ним обов’язку щодо громади і власної родини, турботу про її гідність:: «...а як прийде набор, то певно тобі лоб забриють, бо ти сирота, за тебе нікому заступитись; і дядьки скажуть: «Ми тебе поїли, зодягали і до розуму довели, служи за нашу чергу». А що тогді буде з Марусею? Ні жінка, 
ні удова; звісно, як салдаток шанують: як саму послідню паплюгу, і ніхто і не вірить, щоб була салдатка, та й чесна. Та й троха чи й не так! Де їй за полками таскатись? А молоде, дурне, попадеться ледачим людям, наведуть на усе злеє. Худобу розтаскають, повіднімають, хто їі защитить? Діточки без доглядання, у бідності, у нищеті, без науки, без усього помруть або - не дай Боже! бездільниками стануть. А вона затим ізстаріється, немощі одоліють, бідність, калічество... тільки що в шпиталь, до старців! (Сказав се та й заплакав, як мала дитина). Не приведи, Господи, і ворогу такої судьби!..» [ 567, с.80]. Настанови батька спрямовані на утримання доньки в руслі традиції, що забезпечить їй запевнене становище в громаді і збереже від маргіналізації і втрати «чесності», що є головною чеснотою жінки в патріархальному суспільстві.

Натомість саме Г.Квітка-Основ'яненко пропонує українському читачеві й інший типаж, чи не більш широко розтиражований українською літературою образ дівчини, що переступила через заведений звичай і стала покриткою. Мова йде про повість «Сердешна Оксана» та іï однойменну героїню. Провину за життєву драму дівчини, що не змогла втриматися в рямцях заведеного звичаю, письменник покладає не лише на легковажність і норовливий характер самої героїні, яка прагнула досягнути життєвого успіху через стосунки з офіцером, але й на неповноцінність виховного процесу в родині, позбавленій батьківського керівництва та нагляду. Мати Оксани Векла не спроможна запобігти лихові, повсякчас викорінюючи в поведінці доньки вияви негідної 3 погляду патріархальної традиції поведінки. Маруся оминає ризиковані молодіжні розваги, веде себе тихо і скромно, постійно перебуваючи під пильною батьківською опікою. Оксана позбавлена цього, а тому їі честь вже з самого початку перебуває в загроженій ситуації. Г.Квітка-Основ’яненко безчестя Оксани стає причиною не лише духовного, але й матеріального занепаду загалом заможної родини, оскільки ऑiі добробут тісно пов’язаний зі статусним становищем в громаді.

Гармонійність, злагодженість і постійна взаємодія всіх членів сім’ї, послух молодших і розумне наставництво старших на думку представників українського 
сентименталізму, є запорукою процвітання селянської родини. Ці уявлення простежуються в ідилічній сцені із «Подражанія Горацію» поета-романтика Левка Боровиковського, яке переспівом оди «Хвала сільському життю» античного поета:

Він тілько що на двір, а жінка на поріг -

Його із радощу вітає,

Вечеря на столі, - а дітвора, як рій

На матку, - батька обсідає.

Як смачно на печі, забравшись на черінь,

Після охоти відпочине!

Як завтра весело покине свій курінь

І знову до роботи кине!.. [568]

Цей образ рустикального раю співзвучний 3 виписаним Тарасом Шевченком у поезії «Садок вишневий біля хати». Однак у шевченківському варіанті відчувається усвідомлення поетом конечності ідеального селянського раю. Вона ледь усвідомлена, але кидає місток до руйнування патріархальної ієрархії, що ховається у невинних рядках: «...а мати хоче научати, / так соловейко не дає» [569, с.14]. 3 цього приводу Г.Грабович зауважує: «Первинність матері й формування навколо неї сім’ї стає для нього глибоко психологічною потребою й орієнтацією. Саме на цій основі витворює він ідеал справедливого ладу і згідно з цією уявною моделлю ставить у центр і поглиблює фольклорну традицію» [570, с.48]. Цей амбівалентний материнський світ розгортається трагедією руйнування родинного ідеалу в поемі «Катерина», де батьки під впливом приписів традиційної моралі вимушені вигнати 3 дому доньку-покритку, прирікаючи іï на загибель, а себе на сирітську старість.

Особливо виразно проблема розпаду патріархальної традиції виявляється в творчості Івана Нечуя-Левицького. Його повість «Кайдашева сім'я», попри поширене уявлення про ії комедійність, є глибоко трагічним вислідом глибоких болісних роздумів письменника над питаннями занепаду сімейної духовної традиції. Ключовим у цьому контексті є образ старого Кайдаша, котрий 
намагається стримати наступ нової моралі і утримати життя своєї родини в традиційному руслі. Але вже у сцені з синами спостерігається відсутність домінування батьківського авторитету в родині. Численні описи жіночих чвар остаточно унеможливлюють навернення Кайдашів до традиційних імперативів родинної моралі. Разом 3 деградацією глави сімейства, а пізніше i його безглуздою смертю нівелюється позитивна патріархальна традиція, а родина остаточно розпадається, атомізується, втрачає регулятивну функцію щодо поведінки іï членів. Тому в інтимний простір Кайдашів вимушена втручатися громада: «Волосний 3 писарем та кількома громадянами повели в волость Кайдашенків, їх жінок та Кайдашиху. Вони насилу розплутали їх справу i присудили карпові одірвати хату й поставити окроми на своєму городі, бо Лаврін, як менший син, мав право зостаться в батьковій хаті і за те був повинен додержать матір до смерті. Громада присудила розділити грунт між Кайдашенками пополовині» [19, II, с.263]. Таким чином саме громада перебирає на себе функцію, яка, як раніше було спостережено, виконувалася старшими в родині. І. Нечуй-Левицький таким чином фіксує перехід до загалом невластивої українській спільноті ситуації конфлікту поколінь.

Ще більш виразно згубний вплив відсутності твердих моральних принципів у батьків на долю їхніх дітей простежується в новелі Михайла Коцюбинського «Подарунок на іменини». Досить сумнівна моральність матері, колишньої повії, та батька, котрий задля просування по службі презентує інтимні послуги дружини начальству, вступають в гострий конфлікт зі світоглядом синагімназиста. Парадоксально, але батьки самі доклали зусилля для виховання дитини в зовсім відмінній від власної морально-етичній парадигмі, а отже момент втрати дитячих ілюзій щодо близьких людей стає для нього особливо травматичним, аж до суїцидальних намірів. Водночас батько неспроможний усвідомити причини такої гострої реакції сина, оскільки його життєва психологія дозволяє угоди $з$ совістю, абсолютно неприйнятні для сина. М. Коцюбинський остаточно фіксує розрив поколінь в в момент переходу українства до 
індустріального суспільства, якого в герметичному феодальному патріархальному світі не було.

Таким чином українська література протягом XIX - початку XX століть чітко фіксує зміну суспільних моральних імперативів в українському оціумі, передачу функцій їх вироблення, збереження і прищеплення молоді від родини до суспільних інституцій. 